\title{
MODEL PEMBELAJARAN THINK PAIR SHARE BERBANTU MEDIA MONOPOLI PADA PEMBELAJARAN MATEMATIKA
}

\author{
Widia Astuti ${ }^{1}$, Isnani ${ }^{2}$, Wikan Budi Utami ${ }^{3}$, Fikri Aulia ${ }^{4}$ \\ Program Studi Pendidikan Matematika Universitas Pancasakti Tegal ${ }^{1,2,3}$ \\ Program Studi Bimbingan dan Konseling Universitas Pancasakti Tegal ${ }^{4}$ \\ e-mail:wikan.piti@gmail.com, piti.kasep@gmail.com
}

\begin{abstract}
ABSTRAK
Tujuan penelitian ini adalah untuk mendeskripsikan prestasi belajar matematika peserta didik yang diajar menggunakan model pembelajaran Think Pair Share berbantu media monopoli pada materi aritmatika sosial kelas VII SMP Negeri 13 Kota Tegal. Jenis penelitian ini adalah penelitian eksperimen dengan pendekatan kuantitatif. Teknik pengumpulan data yang digunakan adalah tes, dokumentasi dan angket. Sampel dalam penelitian ini adalah peserta didik kelas VII E dan VII F. Kelas VII E adalah kelas eksperimen dan kelas VII F adalah kelas kontrol. Hasil penelitian menunjukkan bahwa prestasi belajar peserta didik mencapai $60 \%$ berarti bahwa lebih besar dari standar sekolah, minat belajar matematika mencapai 75\%, berarti minat berpengaruh positif terhadap prestasi belajar matematika peserta didik. Prestasi peserta didik yang diajar menggunakan model pembelajaran Think Pair Share berbantu media monopoli lebih baik dari pada model pembelaaran konvensional.
\end{abstract}

Kata kunci: Think Pair Share, Minat belajar, Prestasi peserta didik

\section{PENDAHULUAN}

Pendidikan pada dasarnya suatu proses untuk membantu manusia dalam mengembangkan potensi dirinya, sehingga mampu menghadapi setiap perubahan yang terjadi dalam kehidupan. Pada pembukaan UUD 1945 alinea ke-4 menyebutkan bahwa tujuan pendirian Negara Republik Indonesia antara lain adalah mencerdaskan kehidupan bangsa. Pendidikan dapat dikatakan bagian dari kehidupan semua orang yang wajib untuk diikuti karena mempunyai peran penting untuk mengembangkan potensi diri dan meningkatkan kualitas kehidupan yang lebih baik (Afrianti,2018:101102).

Hal ini berbanding lurus dengan pembelajaran matematika di sekolah yang bertujuan untuk membentuk karakter peserta didik yang mampu berfikir kritis, logis, sistematis dan memiliki sifat objektif, jujur, disiplin dalam memecahkan suatu 
permasalahan baik di bidang matematika maupun pada bidang lainnya dalam kehidupan sehari-hari.

Keberhasilan pembelajaran matematika dapat diukur dari keberhasilan peserta didik yang mengikuti kegiatan pembelajaran tersebut. Keberhasilan itu dapat dilihat dari tingkat penguasaan materi serta prestasi belajar, maka semakin tinggi pada tingkat pula tingkat keberhasilan pembelajaran.

Berdasarkan hasil observasi diperoleh informasi bahwa pembelajaran dengan cara konvensional memiliki minat belajar matematika yang masih rendah hal ini dapat dilihat dengan hasil prestasi belajar matematika UAS semester 1 masih banyak peserta didik yang belum mencapai KKM. Nilai rata - rata UAS semester 1 kelas VII tahun pelajaran 2018/2019 hanya mencapai 3,36 dan nilai belum mencapai KKM yaitu 70. Pesserta didik yang memperoleh nilai diatas KKM hanya $12,5 \%$ dan yang memperoleh dibawah KKM sebanyak $87,5 \%$.

Dalam hal ini diambil model pembelajaran Think Pair Share berbantu media monopoli yang akan diterapkan sebagai perbandingan dengan model pembelajaran konvensional, kombinasi permainan akan menciptakan belajar matematika bukanlah hal yang menakutkan namun membuat pemikiran peserta didik bahwa belajar matematika itu menyenangkan dan mudah, sehingga diharapkan dapat meningkatkan prestasi belajar matematika peserta didik (Yandari, 2017:12).

Salah satu model pembelajaran yang dapat membangun kepercayaan diri peserta didik dan mendorong partisipasi mereka dalam kelas adalah model pembelajaran Think Pair Share, Model pembelajaran ini membantu peserta didik lebih aktif, kreatif serta dilatih untuk berfikir sendiri dalam menjawab dan memecahkan masalah (Santri, 2017:9).

Berdasarkan penelitian yang dilakukan Afrianti (2018:109) diperoleh hasil aktivitas dan prestasi belajar matematika peserta didik yang diajar menggunakan model pembelajaran Think Pair Share lebih efektif daripada peserta didik yang diajar menggunakan model pembelajaran Snowball Throwing. 
Penelitian yang dilakukan Isnani (2011) terdapat pengaruh positif keaktifan dan keterampilan proses terhadap prestasi belajar siswa pada pembelajaran metode Think Pair and Share berbantuan CD Interaktif.

\section{METODE PENELITIAN}

Pendekatan yang digunakan dalam penelitian ini adalah pendekatan kuantitatif karena data yang diperoleh berupa angka dan memungkinkan digunakan teknik analisis data dengan statistika. Pendekatan kuantitatif digunakan untuk meneliti populasi atau sampel tertentu dan teknik pengambilan sampel umumnya dilakukan secara random serta pengumpulan datanya menggunakan instrumen penelitian Menurut Sugiyono (2017:11). Jenis penelitian ini yang digunakan adalah eksperimen yaitu mencari hubungan sebab akibat pada kelas eksperimen dan kelas kontrol. Penelitian ini menggunakan desain eksperimen dan kontrol dengan tipe post test only sebab desain ini dapat menjamin kesetaraan kelompok eksperimen dan kontrol dengan metode acak (randomisasi) dalam memilih subjek penelitian. Dalam penelitian ini yang diuji adalah minat dan prestasi belajar peserta didik yang diajar menggunakan model Think Pair Share berbantu media monopoli.

Populasi dalam penelitian ini adalah peserta didik kelas VII Sekolah Menengah Pertama (SMP) Negeri 13 Kota Tegal. Penelitian ini dilaksanakan selama satu bulan yaitu dibulan Maret - April semester genaptahun ajar 2018/2019 dan dilakukan sebanyak 6 7 kali pertemuan untuk masing - masing kelas dengan materi ajar aritmatika sosial. Pengambilan sampel dilakukan menggunakan teknik cluster random sampling. Teknik cluster random sampling yaitu teknik pengambilan sampel secara acak berdasarkan kelas/kelompok. Teknik ini dipilih karena diasumsikan kelas yang ada dalam penelitian ini mempunyai kemampuan yang sama (Sugiyono, 2012:62). Sampel yang diperoleh dari pengambilan tersebut yaitu kelas VII E sebagai kelas eksperimen dan kelas VII F sebagai kelas kontrol.

Pengumpulan data dalam penilitian ini menggunakan teknik tes, dokumentasi, dan angket. Teknik tes digunakan untuk mengukur keterampilan, pengetahuan, intelegensi, kemampuan dan bakat yang dimiliki oleh perseorangan maupun kelompok. (Arikunto, 
2014:193). Instrument tes yang digunakan berbentuk pilihan ganda sejumlah 30 butir soal.

\section{HASIL PENELITIAN DAN PEMBAHASAN}

Berikut akan dideskripsikan hasil dari penelitian dan pembahasan yang sudah diperoleh dari hasil eksperimen di lapangan.

Tabel 1. Deskripsi Data Prestasi Belajar Matematika Peserta Didik

\begin{tabular}{lcc}
\hline \multicolumn{1}{c}{ Nilai } & \multicolumn{2}{c}{ Hasil Prestasi Belajar } \\
& Kelas Eksperimen & Kelas Kontrol \\
\hline Jumlah & 2284 & 1716 \\
Mean & 71,4 & 53,6 \\
Median & 68 & 56 \\
Modus & 64 & 56 \\
St.Deviasi & 13,56 & 17,56 \\
Varian & 183,9 & 310,6 \\
Max & 96 & 78 \\
Min & 52 & 28 \\
Koefisien Variansi (CV) & 2,575 & 5,794 \\
\hline
\end{tabular}

Berdasarkan tabel 1 dapat diketahui bahwa mean hasil prestasi belajar matematika kelas eksperimen lebih tinggi daripada kelas kontrol. Hal tersebut menunjukkan bahwa prestasi belajar matematika yang diajar menggunakan model pembelajaran Think Pair Share berbantu media monopoli mencapai target.

Tabel 2. Hasil Rekapitulasi Perhitungan Minat Belajar Peserta Didik.

\begin{tabular}{llc}
\hline No & Kesimpulan & $\%$ Hasil \\
& & $19 \%$ \\
1 & Tinggi & $16 \%$ \\
2 & Sedang & $66 \%$ \\
3 & Rendah & 6 \\
\hline
\end{tabular}

Berdasarkan tabel 2 diperoleh sebanyak 85\% peserta didik pada kelas eksperimen memiliki kriteria minat tinggi dan sedang. Hal ini menunjukkan bahwa penerapan model pembelajaran Think Pair Share berbantu media monopoli pada materi aritmetika sosial di SMP Negeri 13 Kota Tegal telah mencapai kriteria keberhasilan pembelajaran yang diterapkan yaitu $75 \%$ peserta didik mencapai kriteria sedang dan tinggi. Hasil ini sesuai dengan penelitian Isnani (2011) bahwa ada pengaruh positif 
keaktifan dan keterampilan proses terhadap prestasi belajar siswa pada pembelajaran Metode Think Pair and Share berbantuan CD Interaktif.

Tabel 3. Hasil Perhitungan Regresi

\begin{tabular}{ll}
\hline Uji Regresi Linear & \\
\hline F tabel & 2,4400 \\
F hitung & 1,8781 \\
Karena F hitung < F tabel, maka H0 diterima & \\
Uji Signifikansi Regresi & 4,1700 \\
F tabel & 4,2250 \\
F hitung & \\
\hline
\end{tabular}

Berdasarkan tabel 3, diperoleh data regresi linier yang menunjukan bahwa $F_{\text {hitung(regresio }}=4,2250$ sedangkan $\mathrm{F}$ tabel untuk $\mathrm{dk} 1: 30($ pembilang $=1:$ penyebut $=30)$ pada taraf signifikansi $5 \%=4,1700$. Artinya harga $\mathrm{F}$ hitung $>\mathrm{F}$ tabel maka $\mathrm{HO}$ ditolak, sehingga $\mathrm{F}$ regresi adalah signifikan. Dengan demikian ada hubungan yang signifikan antara variabel minat dan prestasi belajar matematika. Selain itu, $F_{\text {hitung(regresio }}=1,8781$ sedangkan harga $\mathrm{F}$ tabel untuk taraf signifikan $5 \%=2.4400$. Artinya harga $\mathrm{F}_{\text {hitung(regresio }}$

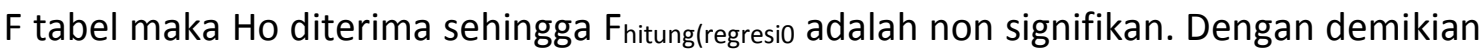
hubungan antara variabel minat peserta didik dengan prestasi belajar matematika adalah linear.

Tabel 4. Hasil Analisis Uji t Pihak Kanan

\begin{tabular}{lll}
\hline$t_{\text {hitung }}$ & $t_{\text {tabel }}$ & Kesimpulan \\
\hline 4,2567 & 1,6550 & $4,2567>1,6550$ \\
\hline
\end{tabular}

Berdasarkan tabel 4, diperoleh hasil analisis uji t pihak kanan $t_{\text {hitung }}>t_{\text {tabel }}$ maka $H_{0}$ ditolak yang artinya prestasi belajar matematika menggunakan model pembelajaran Think Pair Share berbantu media monopoli lebih baik daripada model pembelajaran konvensional.

\section{KESIMPULAN}

Simpulan dari penelitian ini terdapat minat belajar peserta didik kelas eksperimen mencapai target, minat belajar matematika peserta didik mencapai kriteria minat 
sebesar $75 \%$, minat belajar peserta didik berpengaruh positif terhadap prestasi belajar matematika, prestasi belajar matematika yang diajar menggunakan model pembelajaran Think Pair Share berbantu media monopoli lebih baik dibanding dengan model pembelajaran konvensional.

\section{SARAN}

Adapun saran dari hasil penelitian ini adalah bagi pendidik dan calon pendidik dalam penerapan model pembelajaran ini diperlukan persiapan yang baik supaya dalam pelaksanaannya pendidik maupun peserta didik dapat menerima hasil yang lebih baik dibanding dengan metode pembelajaran konvensional.

\section{DAFTAR PUSTAKA}

Afrianti, L., Isnani, I., \&Sina, I. 2018. KEEFEKTIFAN MODEL PEMBELAJARAN SNOWBALL THROWING DAN THINK PAIR SHARE TERHADAP AKTIVITAS DAN PRESTASI BELAJAR MATEMATIKA. Jurnal Dialektika Program Studi Pendidikan Matematika, 5(2), 100 110.

Darmadi. 2017. Pengembangan Model Metode Pembelajaran dalam Dinamika Belajar Siswa. Yogyakarta: CV Budi Utama.

Hamdani. 2011. Strategi Belajar Mengajar. Bandung: Pustaka Setia.

Isnani, M. S., \& Ambarwati, R. 2011. Keefektifan Metode Think, Pair and Share Dalam Pembelajaran Matematika Berbantuan Cd Interaktif Materi Bangun Ruang Kelas V. Cakrawala: Jurnal Pendidikan, 6(2).

Lestari, K.E. dan Yudhanegara, M.R. 2017.Penelitian Penidikan Matematika. Bandung: PT RefikaAditama.

Hamdayana, Jumanta. 2017. Model dan Metode Pembelajaran Kreatif dan Berfikir, Bogor: Galih Indonesia.

Santri, D. A., Darmadi, I. W., \&Kamaluddin, K. Pengaruh Model Pembelajaran Think Pair Share Berbantuan Alat Praktikum Sederhana terhadap Hasil Belajar SiswaKelas VIII SMP Negeri 13 Palu. Jurnal Pendidikan Fisika Tadulako Online (JPFT), 4(4).

Suprijono, A. 2017. Cooperative Learning. Yogyakarta: PustakaPelajar

Yandari, I. A. V., \&Kuswaty, M. 2017. Penggunaan Media Monopoli Terhadap Peningkatan Kemampuan Pemahaman Konsep Matematis Peserta Didik Kelas V Sekolah Dasar. Jurnal Pendidikan Sekolah Dasar, 3(1), 10-1 